\title{
BONE MEAL AS ALTERNATIVE TREATMENT FOR ACIDIC AND METAL CONTAMINATED ACID MINE DRAINAGE WATER EFFLUENT: LAB SCALE
}

\author{
${ }^{1}$ Carolyn Payus, ${ }^{1}$ Olga David and ${ }^{2}$ Moh Pak Yan \\ ${ }^{1}$ Environmental Science Program, \\ ${ }^{2}$ Industrial Chemistry Program \\ School of Science and Technology, Universiti Malaysia Sabah, Malaysia
}

Received 2014-01-22; Revised 2014-01-23; Accepted 2014-03-03

\begin{abstract}
The typical methods of treatment for acidic and metal contaminated water effluent such as the Acid Mine Drainage (AMD) will always focus on either civil engineering methods, such as disposal, excavation, drainage and encapsulation or process based technologies such as effluent washing and treatment. These techniques are not environmental friendly, costly and unsustainable, thus environmental damaging. Nowadays, there is a growing need for an alternative remediation treatment that is innovative and more natural in order to prevent pollution in the environment. Therefore, in this study, a new alternative treatment, that is more organic, biodegradable and cost effective, using bone meal was presented. In this research, bone meal comprising of chicken bones were used as an alternative passive treatment to determine its potential in neutralizing and removing heavy metals from the abandoned cooper mine, Mamut Acid Mine Drainage (AMD) waste water effluent. A pretreatment process for bone meal was performed by incineration process where it was heated up in the furnace at $500^{\circ} \mathrm{C}$ for $24 \mathrm{~h}$ after it was cleaned, crushed, boiled and dried. Batch experiment test has been carried out to test whether the selected bone meal sizes 45 , 75 and $150 \mu \mathrm{m}$ was able to neutralize the AMD Mamut water samples. Inductive Plasma Couple-Atomic Emission Spectrometry (ICP-AES) test was carried out to test the concentration of the heavy metals before and after the treatment. The surface morphology of bone meal was examined by Scanning Electron Microscopy (SEM). Enlargement of pores after the neutralization treatment was seen on the surface morphology of the bone meal by SEM analyses. A significant rising of pH from 2.98 to 5.69 within 6 h 30 min was observed during neutralization process and $99 \%$ removal of $\mathrm{Fe}, \mathrm{Zn}, \mathrm{Al}, \mathrm{Cu}$ and $36 \%$ removal of $\mathrm{Mg}$ concentration was achieved after the treatment through the neutralization treatment of the AMD waste water effluent. The results from this study conclude that bone meal has the potential to neutralize and remove heavy metals from acidic and metal contaminated AMD waste water effluent.
\end{abstract}

Keywords: Bone Meal, Acid Mine Drainage (AMD), Passive Treatment, Neutralization, Remediation

\section{INTRODUCTION}

Remediation treatment of metal contaminated water effluent such as the Acid Mine Drainage (AMD) is an important environmental issue because of health considerations and pressure for reuse of the effluent to a usable form of water resource. The typical methods of remediation will always focus on either civil engineering methods, such as disposal, excavation, drainage and encapsulation or process based technologies such as effluent washing and treatment. These techniques are not environmental friendly, costly and unsustainable, thus environmental damaging. Nowadays, there is a growing need for an alternative remediation treatment, innovative

Corresponding Author: Carolyn Payus, Environmental Science Program, School of Science and Technology,

Universiti Malaysia Sabah, Malaysia 
and more natural way in order to prevent pollution in the environment. Therefore, in this study, a new alternative way, that is more organic, biodegradable and inexpensive, using bone meal (group of calcium phosphate) addition was presented in this research.

The usage of bone meal for soil remediation has been done for contaminated soil remediation in previous researchers (Deydier et al., 2003; Hodson et al., 2001; Sneddon et al., 2008), however this is the first study to performed onto contaminated waste water effluent. Many metal phosphates (such as; plumbum, zinc, cadmium) are highly insoluble with coefficients of $10^{-60}$ to $10^{-80}$ solubility and are stable over almost the entire range of conductivity and $\mathrm{pH}$ conditions in natural environment (Nriagu, 1984). If pollutant metals in contaminated waste water effluent could be converted into metal phosphates, then the metals would be immobilized in situ and with the low solubility their bioavailability would be reduced (Suzuki and Iwao 1982; Nriagu 1974). Theoretically based on immutable chemical relationships, such passive treatment is fully applicable and sustainable.

Acid Mine Drainage (AMD) is formed from sulphide minerals that are exposed to oxidizing conditions in coal and metal mining, highway construction and other largescale excavations (Skousen et al., 2000). It is the production of mine impacted water in mining areas that happens all over the world (Robinson-Lora and Brennan, 2009a). When sulphide ores containing large quantities of pyrite is discarded in the tailings pond, it produced sulphuric acid (AMD) when exposed to water and oxygen (Allan, 1988). The ferrous iron produced is then oxidized to ferric ions which become the dominant oxidizing agent of the exposed sulphide minerals. Mine wastes may affect the filter feeding or respiratory structures, caused gill damage in fishes or increased oxygen consumption organisms. Not only that, but at lesser rates of sedimentation, benthic organism food supply is also blocked. In addition, many components of mining waste are lethally or chronically toxic to fish or cause sub-lethal effects (Allan, 1988).

This study was conducted to analyze whether bone meal can be used to neutralize and remove heavy metals from the acid mine drainage water sample from ex-copper mining site based on the acid-base reaction. This is because when bone meal reacts with AMD it will produce salt. According to Barrow and Shahidi (2007) bone has calcium phosphate as its main component which is used in strengthening teeth, bones, nerve function and other enzymatic reactions. Calcium has been widely used in many industries such as food industry and construction industry. Small fish bone is an important source of calcium and it can increase calcium bioavailability (Larsen et al., 2001), and thus calcium as an alkali will be used to neutralize the acid mine drainage and remove the dissolved heavy metals as well. Bone meal which will consist of chicken bones and fish bone are selected because they are potential source to obtain calcium. The idea of using bone meal as a neutralizer evolved from the usage of crab shell, tree bark and egg shells to neutralize acid mine drainage. Those said materials have the buffering capacity for recovering acidic waters because like crab shell it contains calcium carbonate (Robinson-Lora and Brennan, 2009b). Other than that, bones are biodegradable; it can be degraded by the environment so it causes less complication to the environment. In terms of economic benefit, they are more economic feasible since they are waste materials.

\section{MATERIALS AND METHODS}

\subsection{AMD Samples}

Samples of Acid Mine Drainage (AMD) water samples were collected from the abandoned mamut cooper mine at the coordinates of $06^{\circ} 01.883 \mathrm{~N}, 116^{\circ}$ $39.300 \mathrm{E}$ at the elevation of $1342 \mathrm{~m}$ using pre-washed 25 $\mathrm{L}$ polyethylene bottles. In situ parameters were taken such as $\mathrm{pH}$, electrical conductivity, salinity, total dissolved solid, turbidity and dissolved oxygen for each points using calibrated portable meters.

\subsection{Bone Meal}

Figure 1 below shows the picture of bone meal that was taken after it was cleaned, boiled, crushed, grinded, sieved and incinerated in furnace. A light grey powder of bone meal was obtained. Two kilograms of bone meal samples were collected from fast food restaurant, KFC. The bones were separated from their meats and rinsed thoroughly using tap water and distilled water to remove the impurities. They were dried inside the dry oven for $120^{\circ} \mathrm{C}$ for overnight. Then, were crushed using the Mortar to get a smaller particle size. After that, they were boiled for $200-300^{\circ} \mathrm{C}$ on a hot plate until it boiled to remove the oil and then they were let to settle and cool down and later was filtered with $45 \mu \mathrm{m}$ membrane filter to remove the oil mixed boiling water. It was then put inside the furnace under temperature $500^{\circ} \mathrm{C}$ for $24 \mathrm{~h}$ to remove the organic matter until light grey powder was formed. Lastly, it was crushed using the grinder and sieve through the mechanical siever to customize the particle size of it at the appropriate level (Sneddon et al., 2008). The sizes that were used in this experimental design are $45 \mu \mathrm{m}$ (325 mesh), $75 \mu \mathrm{m}$ (200 mesh) and $125 \mu \mathrm{m}$ (100 mesh). 


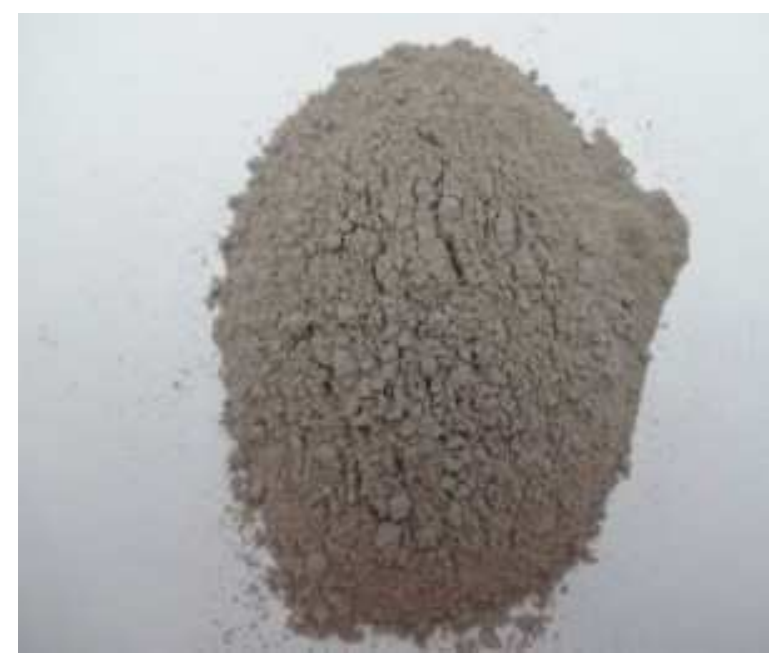

Fig. 1. Crushed bone meal sample for $75 \mu \mathrm{m}$ (200 mesh)

\subsection{Sample Preparation and Analysis}

Preparation of $0.01 \mathrm{NaOH}: 0.4 \mathrm{~g}$ of $\mathrm{NaOH}$ pellet was weight accurately using a electronic balance. It was then transferred into a 1-L volumetric flask. Distilled water was added into the 1-L volumetric flask to dissolve the $\mathrm{NaOH}$ pellet and shaken well. The solution is further diluted to 1L. The resulting solution was shaken well and sealed.

Preparation of phenolphthalein indicator solution: 0.5 $\mathrm{g}$ of phenolphthalein powder was weight using an electronic balance. $50.0 \mathrm{~mL}$ of $95 \%$ ethanol was measured using a measuring cylinder. Phenolphthalein powder was washed into a $100-\mathrm{mL}$ volumetric flask using the $50.0 \mathrm{~mL}$ of ethanol. $50.0 \mathrm{~mL}$ of de-ionized water was then added into the volumetric flask. The resulting mixture was shaken well and sealed.

Neutralization test of AMD samples: In batch experiments (Park et al., 2007), 10 L of AMD sample was transferred into a bucket mixed with bone meal powder. A Jar mixer was set up operating at an interval of $250 \mathrm{rpm}$ and at constant time interval of $20 \mathrm{~min} .1 .0 \mathrm{~g}$ of bone meal powder was measured and added into the water sample for the first $20 \mathrm{~min}$. At every time interval stated, the jar mixer was stopped and $150 \mathrm{~mL}$ of the water sample was taken out for $\mathrm{pH}$ and acidity analysis. Then, $0.5 \mathrm{~g}$ of 100 mesh bone meal powder was measured and added into the water sample and jar mixer was continued until the last $380 \mathrm{~min}$ and the total amount of bone meal powder reached $10 \mathrm{~g}$. The experiment was repeated with 200 mesh bone meal powder and 325 mesh bone meal powders.

Determination of $\mathrm{pH}$ of the AMD sample after treatment: $\mathrm{pH}$ meter was calibrated with a $\mathrm{pH} 4.0$ buffer solution, a pH 7.0 buffer solution and a $\mathrm{pH} 10.0$ buffer solution. $150 \mathrm{~mL}$ of AMD sample was taken out and filtered into a $250 \mathrm{~mL}$ beaker. The probe of the $\mathrm{pH}$ meter was immersed into the AMD sample. The reading on the $\mathrm{pH}$ meter was taken when the value become stable. The $\mathrm{pH}$ meter probe was rinsed with deionized water at every testing interval. The ph meter probe was immersed in a $\mathrm{KCl}$ solution when not in use.

Determination of total acidity of the AMD sample after treatment: From the $150.0 \mathrm{~mL}$ of AMD sample taken out, $20.0 \mathrm{~mL}$ of the AMD sample was filtered into a $250 \mathrm{~mL}$ Erlenmeyer flask using m membrane filter. 4-5 drops of phenolphthalein was added into the AMD sample and shaken well. The AMD sample was titrated with $0.01 \mathrm{~N}$ until endpoint. The titration was carried out twice and all the data was recorded. The acidity of the water sample is calculated using formula as below:

$$
\operatorname{Acidity}(\operatorname{mgCaHA} / \mathrm{L})=\frac{\mathrm{A} \times \mathrm{N} \times 50000}{\mathrm{~V}}
$$

Determination of dissolved heavy metal after AMD treatment: From the $150.0 \mathrm{~mL}$ of AMD sample taken out, $20.0 \mathrm{~mL}$ of AMD sample is filtered with a $0.45 \mathrm{~m}$ membrane filter using vacuum filtration. $5.0 \mathrm{~mL}$ of the filtrate was transferred into a $50 \mathrm{~mL}$ tube and diluted to a volume of $20.0 \mathrm{~mL}$. The resulting solution was added in 4-5 drops of $37 \%$ HNO3 solution and shaken well. The water sample will be transferred onto an auto-sampler of an ICP-AES and analyzed for the concentration of heavy metals. The final concentrations of dissolved metals were recorded and they were calculated using the formula in Equation 1 to get the percentage removal efficiency:

$$
\begin{aligned}
& \% \text { removal } \frac{\text { amount adsorbed } \times 100}{\text { initial amount }} \\
& =\frac{\mathrm{vci}-\mathrm{vci} \times 100}{\mathrm{civ}}=\frac{\mathrm{v}(\mathrm{ci}-\mathrm{cf}) \times 100}{\mathrm{cvi}}=\frac{\mathrm{ci}-\mathrm{cf} \times 100}{\mathrm{ci}} \\
& \mathrm{C}_{\mathrm{i}}=\text { Initial concentration of heavy metal ions }(\mathrm{mg} / \mathrm{L}) \\
& \mathrm{C}_{\mathrm{f}}=\text { Residual solute concentration of equilibrium }(\mathrm{mg} / \mathrm{L}) \\
& \mathrm{V}=\text { Volume of solution from which adsorption occurs }(\mathrm{L})
\end{aligned}
$$

\subsection{Surface Morphology Analyses of Bone Meal Using Scanning Electron Microscope (SEM)}

Preparation of sample was done by taking a small amount of bone meal powder and then it was spinkled on the carbon tape. The excess was blowed with compressed air and lastly particles were coated. 


\section{RESULTS}

\subsection{Scanning Electron Microscope (SEM) Results}

Scanning Electron Microscope (SEM) images under magnification $500 \times 1500 \times$ and $3000 \times$ of bone meal sample before and after treatment are shown below. Before treatment it shows not much of visible pores were seen, only after the treatment there were visible pores observed. The irregular pores occurred due to the reaction of AMD with bone meal surface. Heavy metals are adsorbed to the wall of bone meal causing the pores to clog and causing enlargement of pores while the scattered surface of bone meal has precipitated out to the solution during the treatment.

Figure 2 shows the SEM image of bone meal before treatment while Fig. 3 shows the SEM image of bone meal, both after AMD treatment under 500×and $20 \mu \mathrm{m}$. There is no visible pores seen on the surface of bone meal before the treatment but after the treatment there is visible enlargement of pores seen under the SEM image in Fig. 3. The morphology is represented by fine grain size of $75 \mu \mathrm{m}$ bone meal. Porosity makes in bone makes it a good permeable reactive medium, an excellent condition and competent to support high flow of solution (Conca and Wright, 2006).

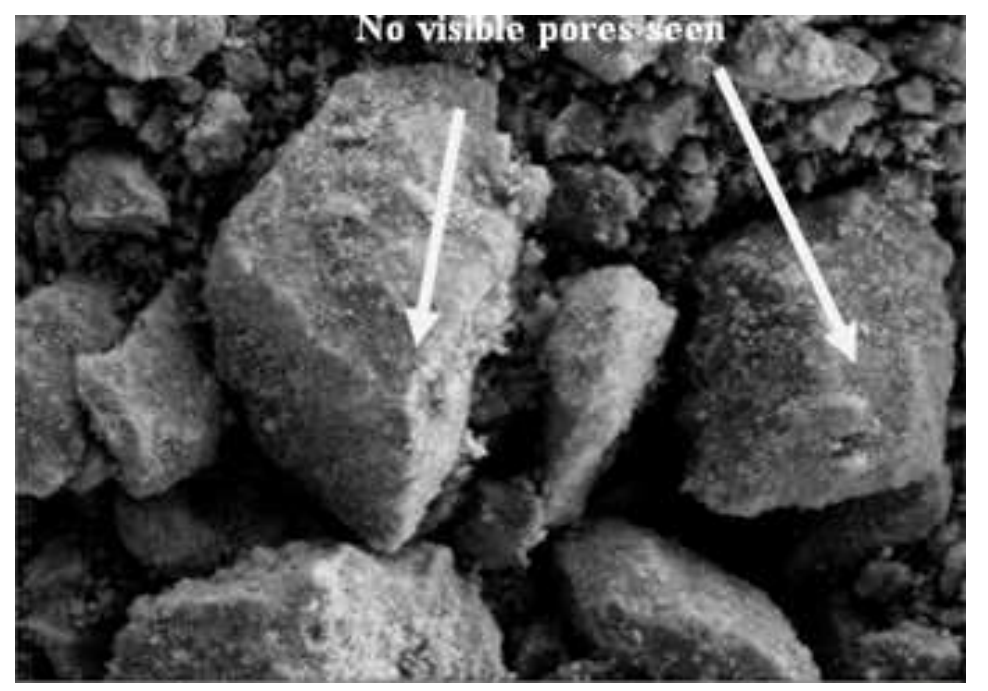

Fig. 2. SEM image of bone meal before treatment under magnification of 500x

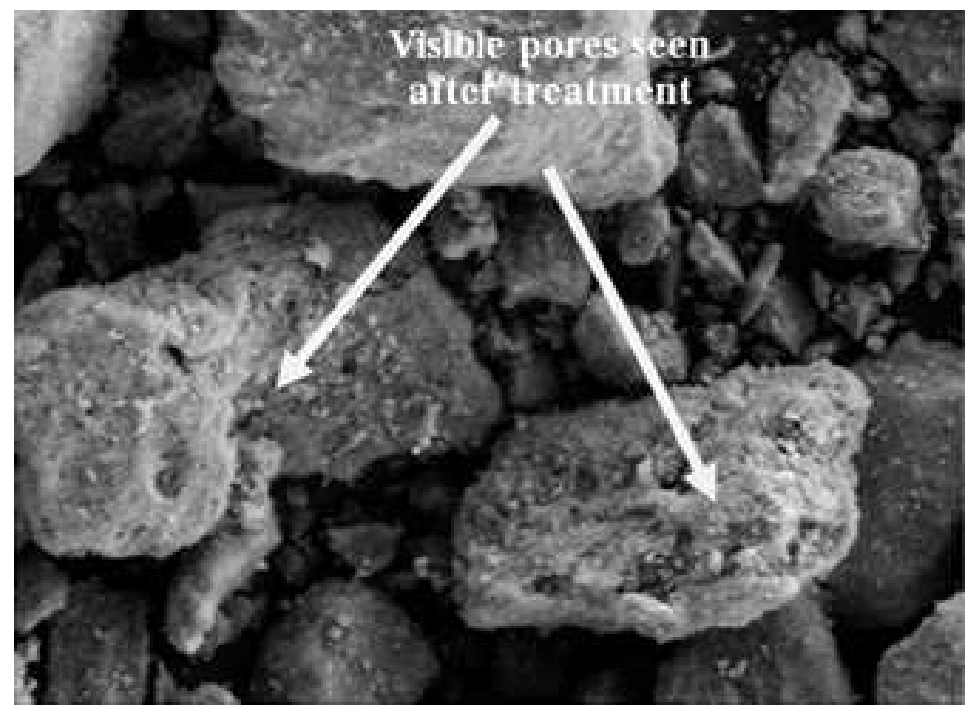

Fig. 3. SEM image of bone meal after treatment under magnification of 500x 
Figure 4 and 6 shows both irregular surface of bone meal before the treatment with AMD. Figure 4 is seen under the image of $10 \mu \mathrm{m}$ resolutions and is focus more under resolution of $2 \mu \mathrm{m}$ for a closer look in as in Fig. 6 and 7. A few lumps can be observed on the bone meal surface in both resolutions in Fig. 5 and 7. After the neutralization treatment of AMD with bone meal, it was observed that the surface of bone meal has a smooth texture and scattered as compared to the surface image before the treatment.

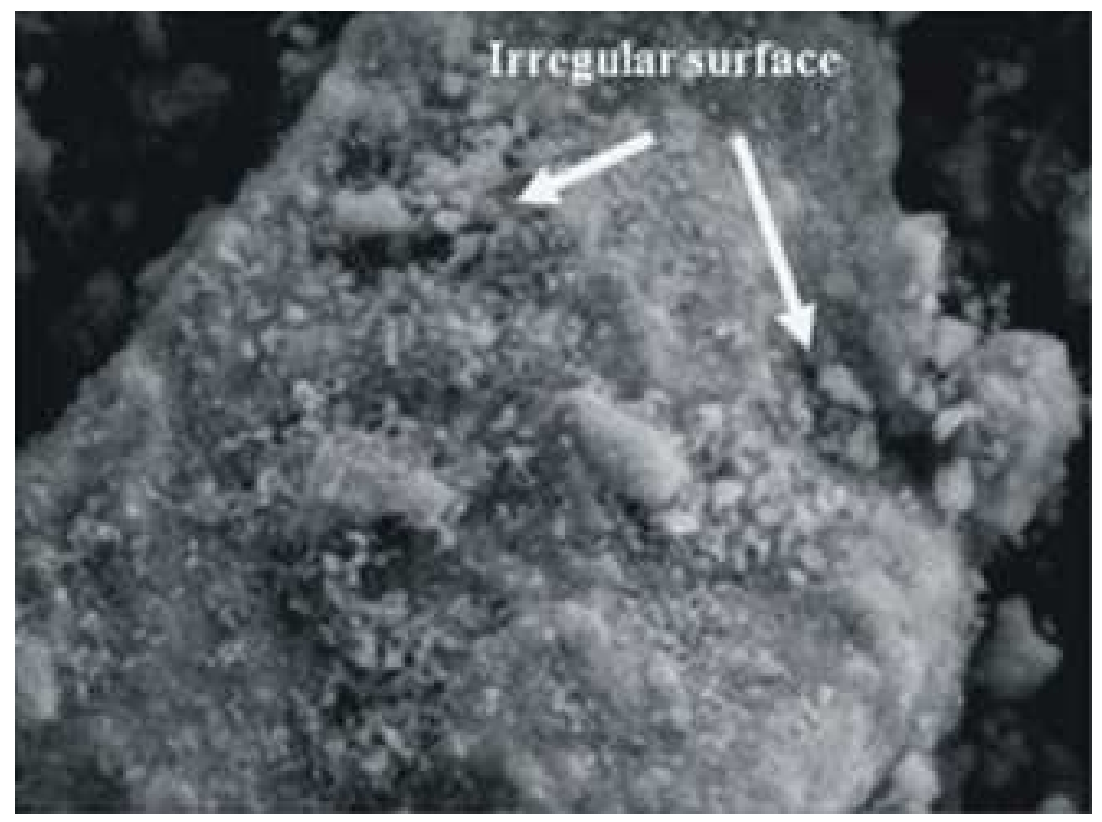

Fig. 4. SEM image of bone meal before treatment under magnification of $1500 x$

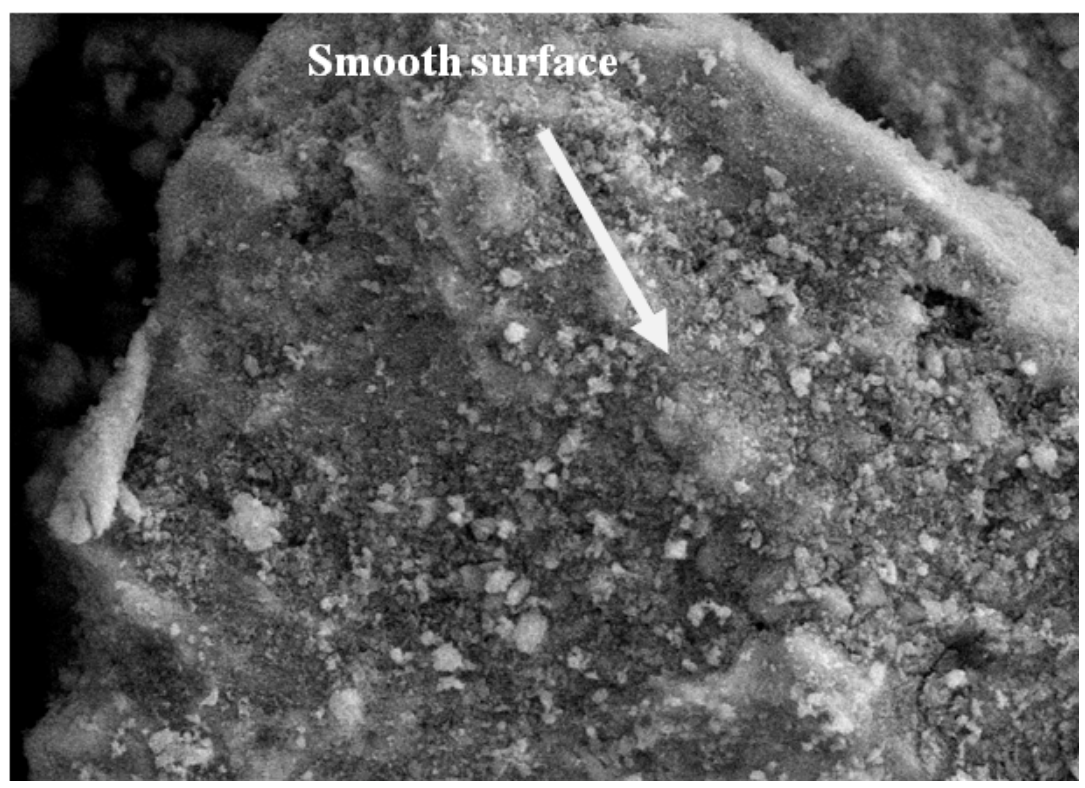

Fig. 5. SEM image of bone meal after treatment under magnification of 1500x 


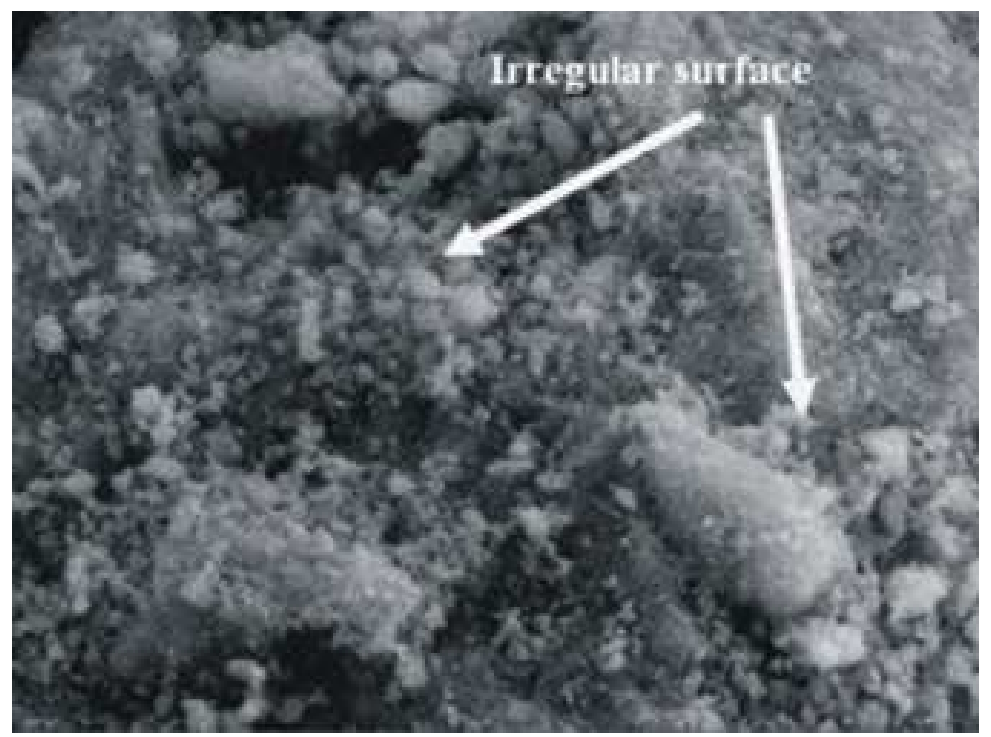

Fig. 6. SEM image of bone meal before treatment under magnification of 3000x

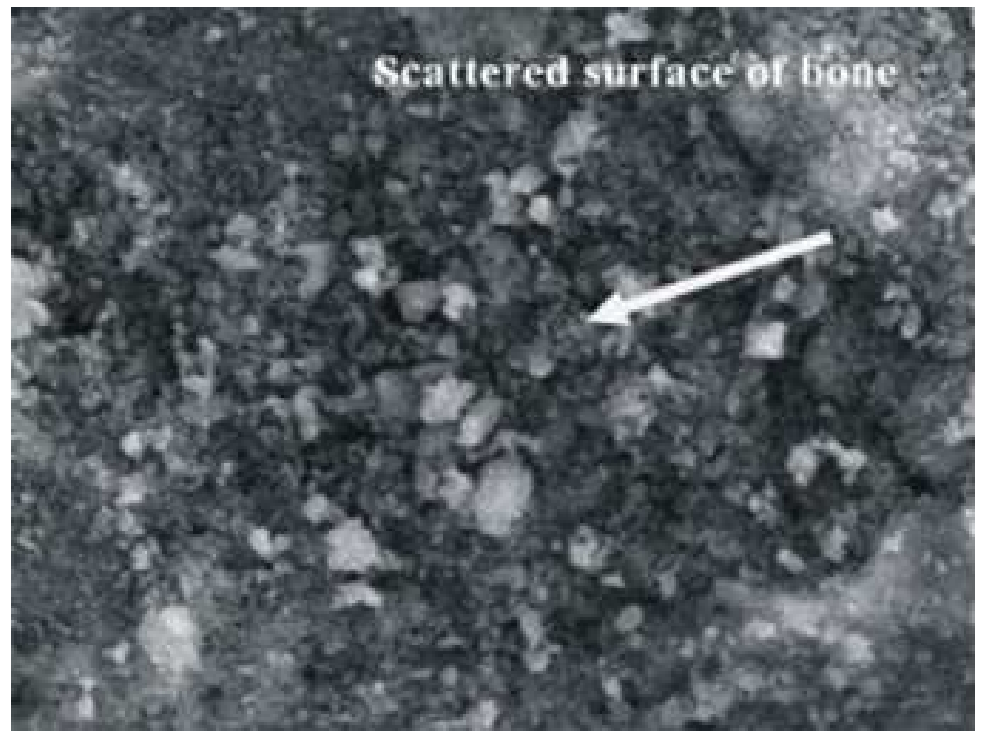

Fig. 7. SEM image of bone meal after treatment under magnification of $3000 \mathrm{x}$

\subsection{Neutralization of AMD With Bone Meal}

The $\mathrm{pH}$ of AMD as seen in Fig. 8, shows a slow increase with increased amount of bone meal used and over longer period of time (contact time).

The $\mathrm{pH}$ increased as more bone meal dissolved in the AMD. According to Hodson et al. (2001) the amount of dissolution was proportional to the amount of bone meal used and the size or surface area of the bone meal. The ability to increase the $\mathrm{pH}$ is associated with the dissolution of calcium hydroxyapatite (CaHA), Ca10(PO4)6(OH)2 from the bone meal reacting with the AMD. It releases salt phosphate, $\mathrm{HPO} 3$ and $\mathrm{OH}$ which will generate the alkalinity. The apatite dissolution equation is simplified as below (Valsami-Jones et al., 1998) Equation 2:

$$
\mathrm{Ca} 10(\mathrm{PO} 4) 6(\mathrm{OH}) 2-\square 10 \mathrm{Ca} 2++6 \mathrm{PO} 43-+2 \mathrm{OH}
$$


Sneddon et al. (2008) explained that the dissolution of bone apatite consumes protons and releases hydroxide ions. Basically, the release of hydroxide ions reduce the total acidity as shown in the
Fig. 9 and increase the overall $\mathrm{pH}$ of AMD treatment with bone meal. The average initial $\mathrm{pH}$ increased from 2.98 to $\mathrm{pH} 5.69$ while the total acidity reduced from 391.25 to $71.25 \mathrm{mg} \mathrm{L}^{-1}$.

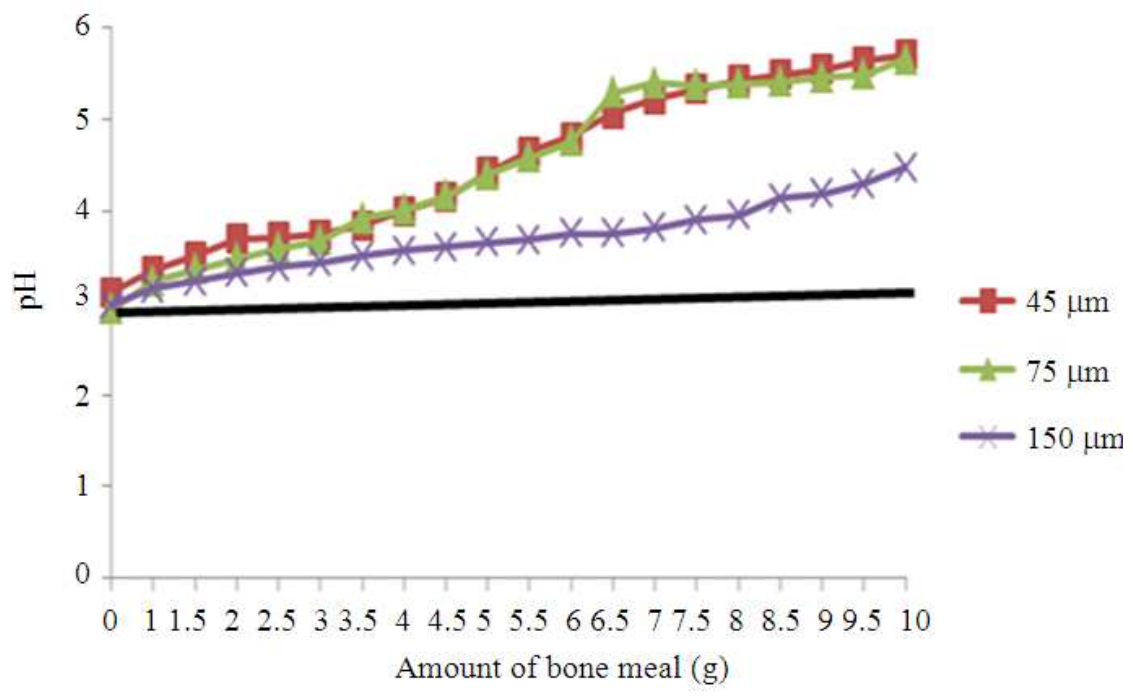

Fig. 8. Final $\mathrm{pH}$ of AMD after neutralization using bone meal for 3 different sizes

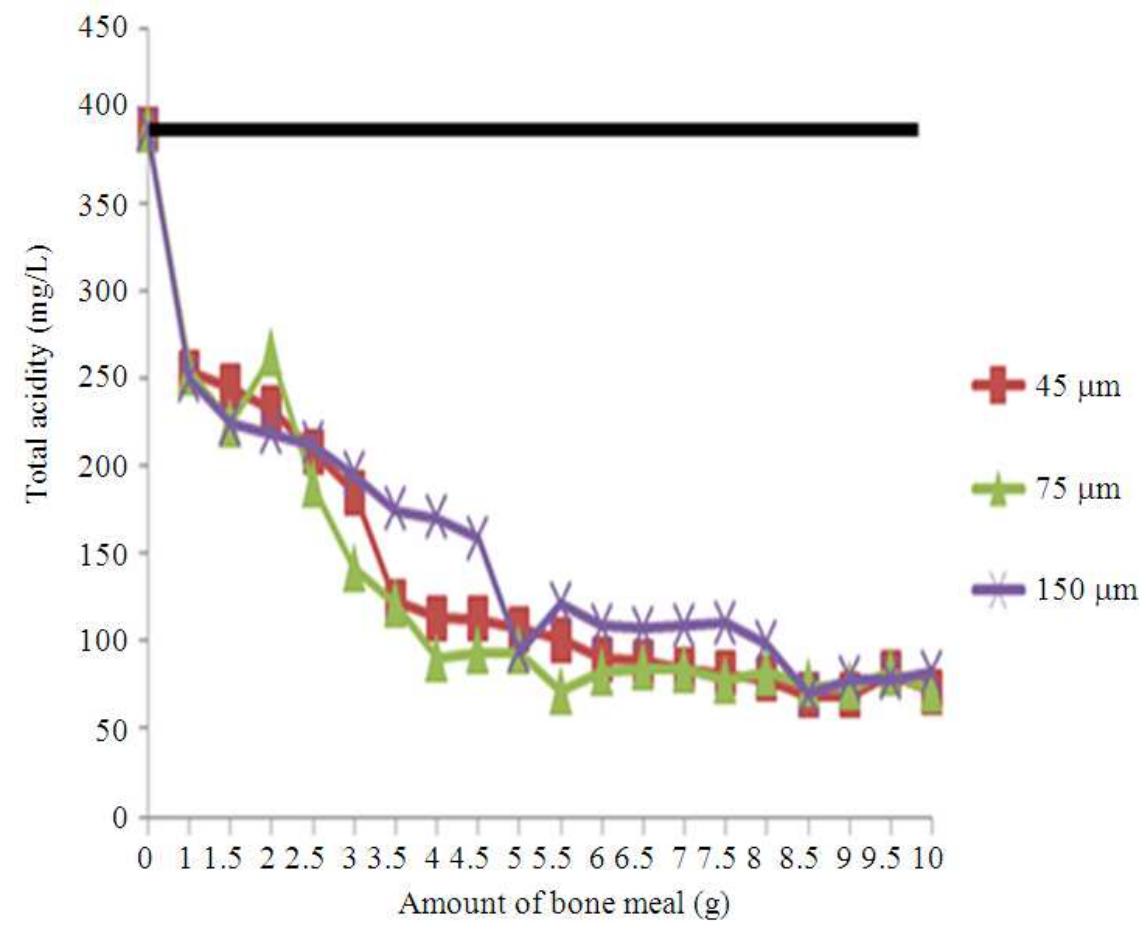

Fig. 9. Graph of total acidity $(\mathrm{mg} / \mathrm{L})$ over amount of bone meal used with different selected sizes 
Different grain sizes of bone meal were used such as 45,75 and $150 \mu \mathrm{m}$ with addition of $1 \mathrm{~g}$ for the first minute $(20 \mathrm{~min})$ and $0.5 \mathrm{~g}$ for the next minute until it reached to $10 \mathrm{~g}$ for a $6 \mathrm{~h}$ and $30 \mathrm{~min}$ duration. Based on the result above, it is observed that the capacity of bone meal in neutralizing the acid mine drainage water sample is dependable on the surface area and amount of bone meal used. For the finest grain $45 \mu \mathrm{m}$, the $\mathrm{pH}$ increased from 3.11 to 5.69 , for grain size 75 $\mu \mathrm{m}$ the $\mathrm{pH}$ increased from 2.93 to 5.64 , for grain size $150 \mu \mathrm{m}$ the $\mathrm{pH}$ increased from 2.98 to 4.47 .

\subsection{Heavy Metal Concentration Before and After Treatment}

Figure 10-14 below show different trends in concentration of $\mathrm{Mg}, \mathrm{Zn}, \mathrm{Al}, \mathrm{Cu}$ and $\mathrm{Fe}$ with different sizes of bone meal over varied weight used. Metal removal in this experiment could involve different mechanisms either through adsorption or precipitation. However, the major contribution could be from physical sorption at low $\mathrm{pH}$ followed by precipitation at higher pH (Daubert and Brennan, 2007).

The concentration of $\mathrm{Mg}$ shows significant inconsistent trend for different size of the bone meal. Fluctuations of heavy metals concentration with the finest grain size occurred throughout the time. Figure 10, from the graph, for size $45 \mu \mathrm{m}$ bone meal there a significant rise in $\mathrm{Mg}$ concentration further away from the initial concentration while for $75 \mu \mathrm{m}$ and $150 \mu \mathrm{m}$ bone meal shows constant decreasing trend. It could be associated with the magnesium element from the bone meal itself leaching out to the AMD water. Another reason would be because metals have different affinity for adsorption sites (Stella, 2008). Since AMD consist of multiply metals such as $\mathrm{Fe}, \mathrm{Zn} \mathrm{Mg}$ and $\mathrm{Cu}$, they may compete with each other for the binding sites during adsorption process. Therefore, adsorption of other metals might lower the removal efficiency of magnesium concentration from the AMD. Thus, it can be concluded that magnesium removal is not efficient with bone meal and it might also have been desorption instead of adsorption (Sneddon et al., 2008).

Figure 11 shows the concentration of $\mathrm{Zn}$ after the treatment with bone meal. A sudden increase observed during the first interval but at the end of the interval it shows a stable decreasing trend for the rest of the intervals. The concentration of $\mathrm{Zn}$ decreases with more dosage of sorbent and longer contact time. This is supported by Rios et al. (2008) stated $\mathrm{Zn}$ concentration tends to increase at longer reaction time and with higher sorbent dosage. Also, past research by Hodson et al. (2001) proved that the addition of bone meal was able to reduce the bioavailability of $\mathrm{Zn}$.

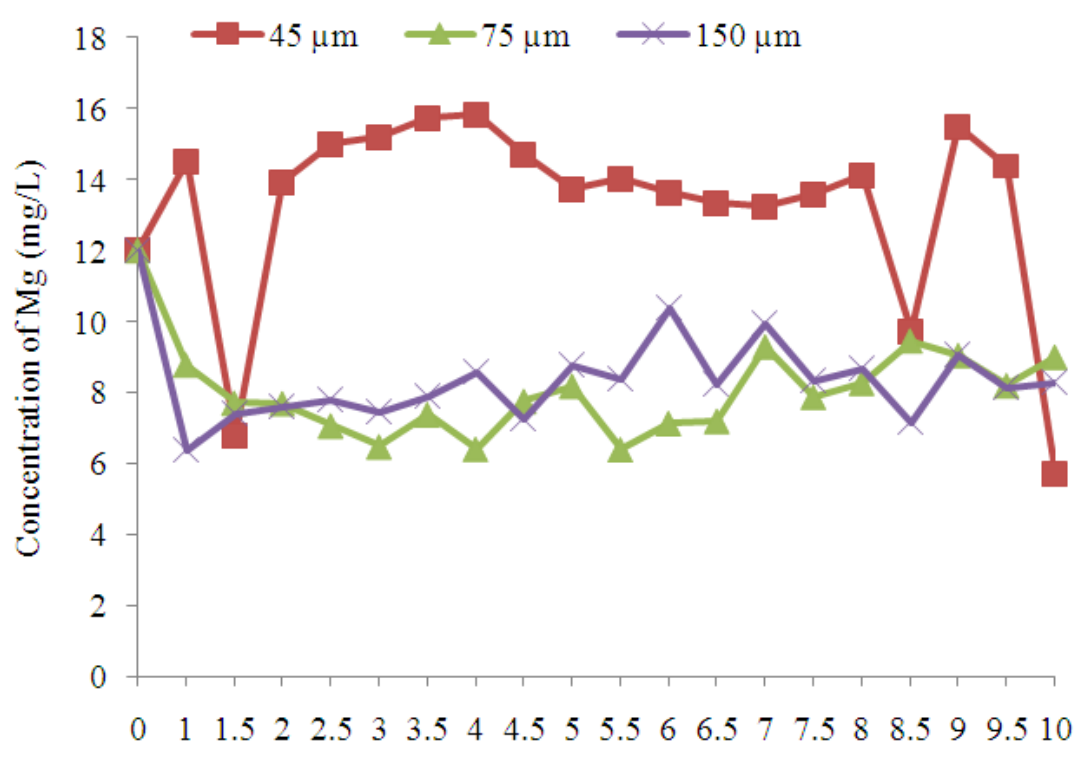

Amount of bone meal (g)

Fig. 10. Graph of Mg concentration (mg/L) of different selected sizes over amount of bone meal used (g) 


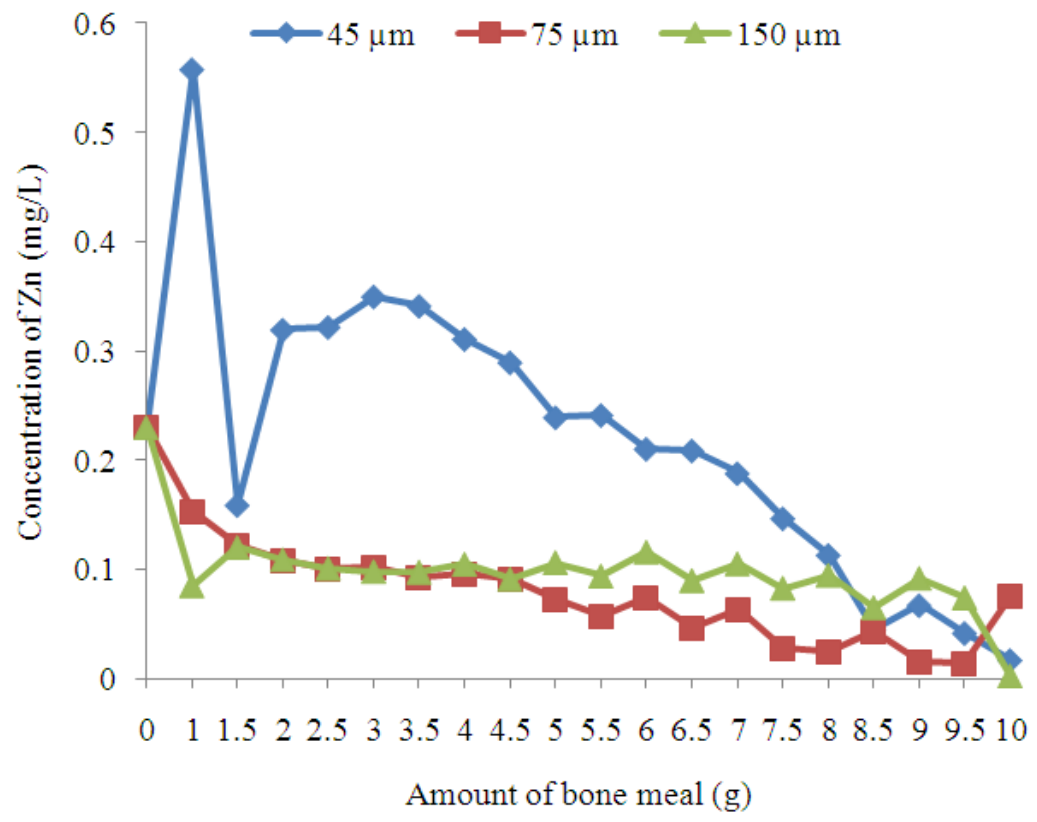

Fig. 11. Graph of $\mathrm{Zn}$ concentration $(\mathrm{mg} / \mathrm{L})$ of different selected sizes over amount of bone meal used (g)

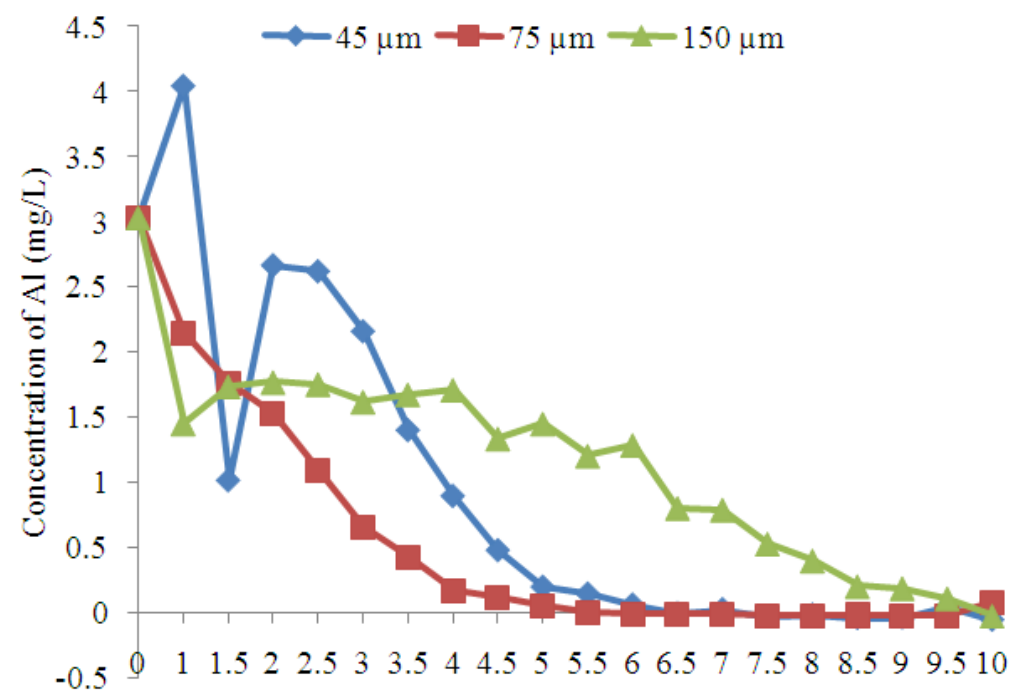

Amount of bone meal (g)

Fig. 12. Graph of $\mathrm{Al}$ concentration ( $\mathrm{mg} / \mathrm{L})$ of different selected sizes over amount of bone meal used $(\mathrm{g})$

Initial concentration of $\mathrm{Zn}$ is $0.234 \mathrm{mg} \mathrm{L}^{-1}$ as the $\mathrm{pH}$ of solution increases to 5.0 shown in Fig. 11 and more dosage of sorbent added, removal of $\mathrm{Zn}$ occurred and the concentration decreases to $0.002 \mathrm{mg} \mathrm{L}^{-1}$. The $\mathrm{pH}$ rise up when favourable dosage was added as it becoming more soluble in the solution of bone meal and AMD. From this study, the removal of $\mathrm{Zn}$ might occur through more than one type of mechanism mainly through adsorption and coprecipitation occurring in partial removal in $\mathrm{pH} 4.0$ to 7.0 (Lee et al., 2002). Past research by Dzombak and Morel (1990) found that for surface precipitation mechanism of heavy metal, it usually includes an initial, rapid, adsorption mechanism followed by a slower surface precipitation. 


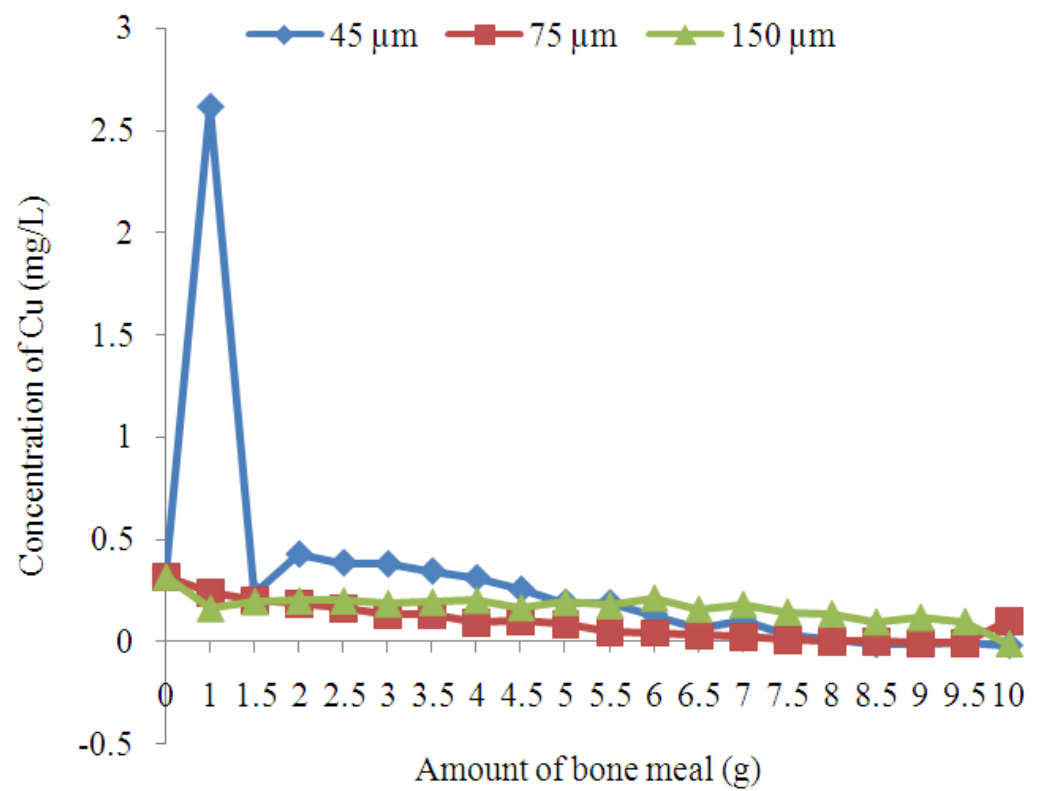

Fig. 13. Graph of $\mathrm{Cu}$ concentration $(\mathrm{mg} / \mathrm{L})$ of different selected sizes over amount of bone meal used $(\mathrm{g})$

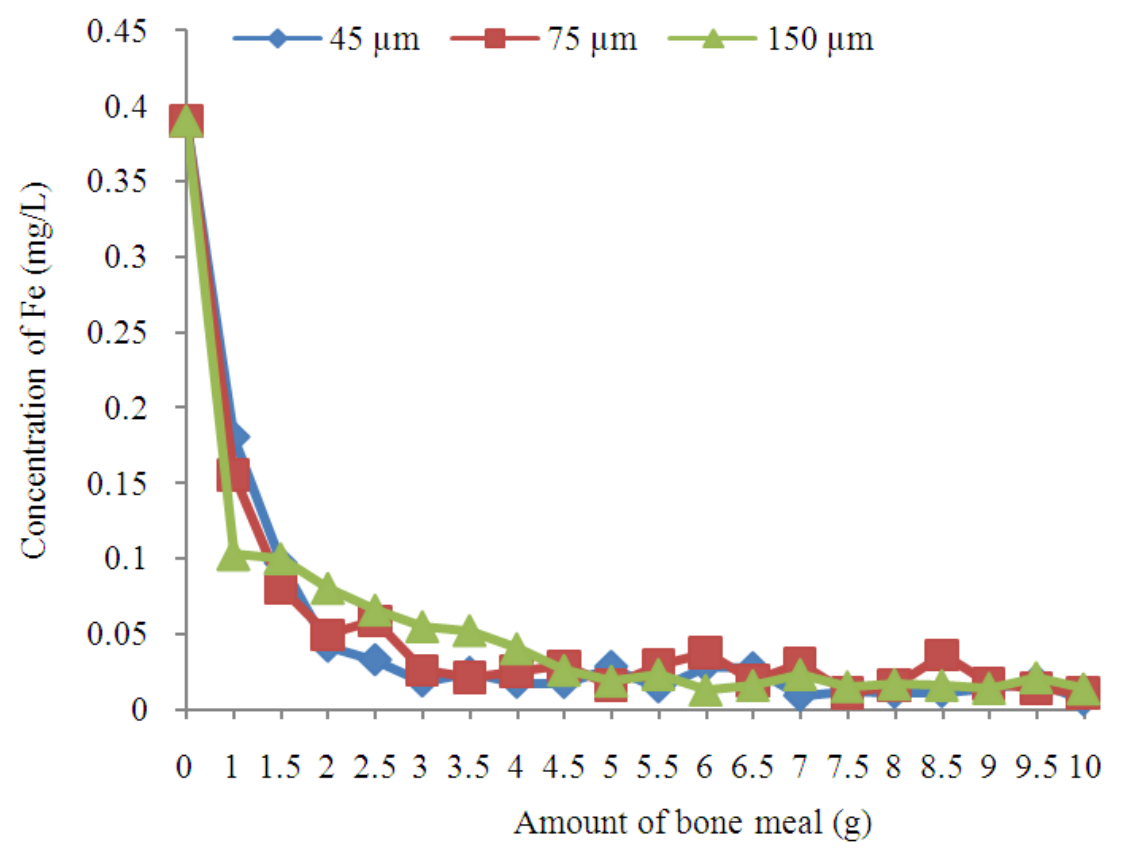

Fig. 14. Graph of Fe concentration $(\mathrm{mg} / \mathrm{L})$ of different selected sizes over amount of bone meal used $(\mathrm{g})$

Figure 12 generally shows a progressive decrease for $\mathrm{Al}$ concentrations after the treatment although there is a slight increased within the first dosage. The initial

concentration of $\mathrm{Al}$ decreased from $3.028 \mathrm{mg} \mathrm{L}^{-1}$ and then dropped to $-0.030 \mathrm{mg} \mathrm{L}^{-1}$ at or below the detection limit. This is because at $\mathrm{pH}$ more than 5.0 the $\mathrm{Al}^{3+}$ starts 
to decreased and form a solid precipitate aluminium hydroxide, $\mathrm{Al}(\mathrm{OH})_{3}$ (Daubert and Brennan, 2007), it would precipitate out of the solution based on their solubiltity product constants $\left(\mathrm{K}_{\mathrm{sp}}\right)$ (McQuarrie and Rock, 1984) and therefore would lower the concentration of $\mathrm{Al}$.

Figure 13 shows the concentration of $\mathrm{Cu}$ after the treatment of AMD with bone meal. An abrupt increase was observed for the first dosage of bone meal addition but somehow is proceed with steady decrease of $\mathrm{Cu}$ concentration until dosage of bone meal increased up to $10 \mathrm{~g}$. Since the minimum solubility for $\mathrm{Cu}$ to precipitates is at $\mathrm{pH} 4.0$ (Lee et al., 2002), it can be seen from this experiment, as the $\mathrm{pH}$ increased up to 4.0 with increasing amount of bone meal used, the removal of $\mathrm{Cu}$ occurred at this phase and reduced the concentration of $\mathrm{Cu}$ at the end of the experiment.

Figure 14 shows the concentration of $\mathrm{Fe}$ after the treatment of AMD with bone meal. The concentration of Fe decreased linearly after the treatment with bone meal. The concentration dropped from $0.392 \mathrm{mg} \mathrm{L}^{-1}$ to 0.01 $\mathrm{mg} \mathrm{L}^{-1}$ where it almost reached a complete removal of $\mathrm{Fe}$ metal in AMD. This result indicates that bone meal has a high efficiency in removing $\mathrm{Fe}$ with progressive decreasing of $\mathrm{Fe}$ concentration for the rest of the intervals. Evangelou (1955) stated $\mathrm{Fe}^{3+}$ can be precipitated as $\mathrm{Fe}(\mathrm{OH})_{3}$ at $\mathrm{pH}$ more than 3.5, a proportion of the dissolved Fe may be precipitated out from the solution. The remaining Fe, therefore is likely to be dominated by $\mathrm{Fe}^{2+}$.

\subsection{Removal Efficiency of Heavy Metals Using Bone Meal}

Table 1 below shows the percentage of removal efficiency of $\mathrm{Fe}, \mathrm{Zn}$ and $\mathrm{Mg}$ at the final concentration for selected different size of bone meal. The highest removal efficiency is $\mathrm{Fe}$ with almost $99 \%$ of removal; the least removal is $\mathrm{Mg}$ average range from 50 to $20 \%$. The other heavy metals, $\mathrm{Al}$ and $\mathrm{Cu}$ have less significant removal efficiency because at certain mesh size it falls below the detection limit. From the concentration of each dominant heavy metals $\mathrm{Mg}, \mathrm{Fe}, \mathrm{Zn}, \mathrm{Al}$ and $\mathrm{Cu}$ (Jopony and Tongkul, 2009), there a significant reduction in respective metals concentration with correspond of increasing metals removals followed by $\mathrm{pH}$ of AMD after the treatment. The trend of metals removal in this experimental results are $\mathrm{Fe}>\mathrm{Zn}>\mathrm{Al}>\mathrm{Cu}>\mathrm{Mg}$. A rapid removal of $\mathrm{Fe}$ and $\mathrm{Zn}$ in this result shows that bone meal has the potential as a metal removal. However, the mechanisms of metal removal by bone meal are complex and should be further examined for a better understanding.
Table 1. Removal efficiency of $\mathrm{Fe}, \mathrm{Zn}, \mathrm{Al}, \mathrm{Cu}$ and $\mathrm{Mg}$ at the final concentration for different size

\begin{tabular}{|c|c|c|c|c|c|}
\hline \multirow[b]{2}{*}{ Size/ metal } & \multicolumn{5}{|c|}{ Removal efficiency (\%) } \\
\hline & $\mathrm{Fe}$ & $\mathrm{Zn}$ & $\mathrm{Al}$ & $\mathrm{Cu}$ & $\mathrm{Mg}$ \\
\hline $45 \mu \mathrm{m}$ & 98.47 & 92.77 & 100.00 & 100.00 & 52.43 \\
\hline $75 \mu \mathrm{m}$ & 97.45 & 67.66 & 97.42 & 68.55 & 25.05 \\
\hline $150 \mu \mathrm{m}$ & 96.68 & 99.15 & 100.00 & 100.00 & 30.77 \\
\hline
\end{tabular}

\section{DISCUSSION}

In past research by Rios et al. (2008) other than the reactivity and mode of metal uptake into the sorbents, the crystal size and morphology of the sorbents are important to trigger its sorption properties. The crystalinity of bone meal is low but according to Hodson et al. (2001) after bone meal is incinerated it increase the crystallinity of bone meal. In which case, as the crystalinity of bone meal increase, it will also increase the surface area, as more pores are exposed because organic matter was removed and this will increase the metal immobilization. In this experiment, the bone meal was incinerated in furnace under $500^{\circ} \mathrm{C}$ until a light grey powder is obtained. However, the images of bone meal shown under SEM are not too clear because it is in a powder form.

It is likely that the increase in surface area of bone meal was accompanied by an increase in the crystallinity of bone structure, which is the porous structure of bones (Hodson et al., 2001). The removal of organic material from the bone through the incineration during the pretreatment process allowed larger pores of the bone exposed. The solubility of the bone meal, phosphate mineral is low in water (Valsami-Jones et al., 1998), therefore it requires a longer period of time contact for neutralization reaction to be more efficient. In this experiment, the $\mathrm{pH}$ of the AMD during treatment is observed at every $20 \mathrm{~min}$ time interval for $6 \mathrm{~h}$ and $30 \mathrm{~min}$.

As shown in this experiment, the grain size bone meal of $45 \mu \mathrm{m}$ and $75 \mu \mathrm{m}$ have shown the highest capability in rising up the $\mathrm{pH}$ up to 5 during the neutralization process as compared to $150 \mu \mathrm{m}$ size of bone meal used. This is because as said by Ahmaruzzaman (2011) decrease in particle size would lead to increase in surface area. The finest size can increase the $\mathrm{pH}$ of AMD higher compared to the other size. During the neutralization process, removal of heavy metals through adsorption mechanism may have taken place. However, it might not depend solely on adsorption mechanism, precipitation of metal hydroxide might have occurred as well. $\mathrm{pH}$ increased as the charge developed 
on the surfaces of the adsorbent, therefore $\mathrm{pH}$ is important in the sorption or removal of the contaminants (Rios et al., 2008). The formation and composition of the sorbent was controlled by $\mathrm{pH}$, chemical composition of the water and the solubilitites of the oxyhdroxide-sulfate complexes of dominant metals such as Fe, Al and Mn. The rising $\mathrm{pH}$ dependence sorption does not solely depend on changes in the sorption coefficients of the trace metals (Lee et al., 2002).

Generally, the principle process contributing towards metal removal during AMD neutralization is precipitation of metal hydroxides (Lee et al., 2002). The removal of heavy metals occurred at $\mathrm{pH}$ values correspond with the optimum precipitation $\mathrm{pH}$ of the respective metal hydroxides. The effective removal of $\mathrm{Fe}$ and $\mathrm{Al}$ at $\mathrm{pH} 4.0$ to 5.0 correspond with the precipitation $\mathrm{pH}$ of $\mathrm{Fe}\left(\mathrm{OH}_{3}\right)$ and $\mathrm{Al}(\mathrm{OH})_{3}$, respectively. The partial removal of $\mathrm{Cu}$ and $\mathrm{Zn}$ at between $\mathrm{pH} 4.0$ and $\mathrm{pH} 7.0$ or $\mathrm{pH} 8.0$ could be attributed to coprecipitation of metals during the precipitation of $\mathrm{Fe}(\mathrm{OH})_{3}$ and $\mathrm{Al}(\mathrm{OH})_{3}$ and adsorption by $\mathrm{Fe}(\mathrm{OH})_{3}$ and $\mathrm{Al}(\mathrm{OH})_{3}$ precipitates (Lee et al., 2002). Where in this experiment the removal efficiency of $\mathrm{Fe}$ is the highest because it reached the minimum solubility at $\mathrm{pH}$ more than 3, enough to precipitate the metal to become metal hydroxide, while $\mathrm{Mg}$ did not show significant removal efficiency because the $\mathrm{pH}$ optimum solubility at $\mathrm{pH} 10$, is not favourable in this experiment. As according to Lee et al. (2002) the most primary factors that influencing the removal of trace metals in AMDcontaminated waters are the $\mathrm{pH}$ range of the drainage system, the relative abundance of dissolved metals, $\mathrm{Fe}, \mathrm{Al}, \mathrm{Mg}, \mathrm{Cu}$ and $\mathrm{Zn}$ and the solubilitites of various $\mathrm{Fe}, \mathrm{Al}$ and $\mathrm{Mn}$ hydroxides and hydroxysulfates.

\section{CONCLUSION}

From this experiment, bone meal shows a positive result as a potential neutralization material for treatment AMD. Initial $\mathrm{pH}$ of AMD changed from 2.98 to 5.69 after addition of $10 \mathrm{~g}$ of bone meal within $6 \mathrm{~h}$ and 30 min. It shows that bone meal has the capability to increase $\mathrm{pH}$ values with more dosage of bone meal as well as to reduce the concentration of heavy metals after the treatment. Basically, the metals that were removed in this experiment were $\mathrm{Fe}, \mathrm{Zn}, \mathrm{Cu}$ and $\mathrm{Al}$. It was observed that the percentage removal efficiency of $\mathrm{Fe}, \mathrm{Zn}, \mathrm{Al}$ and $\mathrm{Cu}$ is $99 \%$ while the percentage removal efficiency of $\mathrm{Mg}$ is $36 \%$. Therefore, it shows that bone meal can neutralize and remove heavy metals in acid mine drainage water effluent by neutralizing treatment in a lab scale. However, the mechanisms of metal removal by bone meal are complex and should be further examined for a better understanding.

\section{REFERENCES}

Ahmaruzzaman, M., 2011. Industrial wastes as low-cost potential adsorbents for the treatment of wastewater laden with heavy metals. Adv. Colloid Interface Sci., 166: 36-59. DOI: 10.1016/j.cis.2011.04.005

Allan, R.J., 1988. Mining Activities as Sources of Metals and Metalloids to the Hydrosphere. In: Metals and Metalloids in the Hydrosphere, Impact through Mining and Industry and Prevention Technology. Technical Documents in Hydrology. Pub. UNESCO, Paris, pp: 45-67.

Barrow, C. and F. Shahidi, 2007. Marine Nutraceuticals and Functional Foods. 1st Edn., CRC Press, ISBN10: 1420015818 , pp: 512

Conca, J.L. and J. Wright, 2006. An Apatite II Permeable reactive barrier to remediate groundwater containing $\mathrm{Zn}, \mathrm{Pb}$ and $\mathrm{Cd}$. Applied Geochem., 21: 2188-2200. DOI: 10.1016/j.apgeochem.2006.06.008

Daubert, L.N. and R.A. Brennan, 2007. Passive remediation of acid mine drainage using crab shell chitin. Environ. Eng. Sci., 24: 1475-1480. DOI: 10.1089/ees.2006.0199

Deydier, E., R. Guilet and P. Sharrock, 2003. Beneficial use of meat and bone meal combustion residue: "An efficient low cost material to remove lead from aqueous effluent". J. Hazardous Materials, 101: 5564. DOI: 10.1016/S0304-3894(03)00137-7

Dzombak, D.A. and F.M.M. Morel, 1990. Surface Complexation Modeling: Hydrous Ferric Oxide. 1st Edn., Wiley, New York, ISBN-10: 0471637319, pp: 416.

Evangelou, V.P., 1995. Pyrite Oxidation and Its Control. 1st Edn., CRC Press, ISBN-10: 0849347327. pp: 293

Hodson, M.E., E. Valsami-Jones, J.D. Cotter-Howells, W.E. Dubbin and A.J. Kemp et al., 2001. Effect of bone meal (calcium phosphate) amendments on metal release from contaminated soils-a leaching column study. Environ. Poll., 112:233-243. DOI: 10.1016/S0269-7491(00)00116-0

Jopony, M. and F. Tongkul, 2009. Acid mine drainage at mamut copper mine, Sabah, Malaysia. Borneo Sci., 24:83-92.

Larsen, T.S., J.A. Kristensen, G. Asmund and P. Bjerregaard, 2001. Lead and zinc in sediments and biota from maarmorilik, west Greenland: an assessment of the environmental impact of mining wastes on an Artic fjord system. Environ. Poll., 114: 275-279. DOI: 10.1016/S0269-7491(00)00214-1 
Lee, G., J.M. Bigham and G. Faure, 2002. Removal of trace metals by coprecipitation with $\mathrm{Fe}, \mathrm{Al}$ and $\mathrm{Mn}$ from natural waters contaminated with acid mine drainage in the ducktown mining distric, Tennessee. Applied Geochem., 17: 569-581. DOI: 10.1016/S0883-2927(01)00125-1

McQuarrie, D.A. and P.A. Rock, 1984. General Chemistry. W.H. Freeman and Company, New York, pp: 743.

Nriagu, J.O., 1974. Fractionation of sulfir isotopes by sediment adsorption of sulfate. Earth Planetary Sci. Lett., 22: 366-370. DOI: 10.1016/0012$821 X(74) 90146-0$

Nriagu, J.O., 1984. Environmental Impacts of Smelters. 1st Edn., John Wiley and Sons, New York, ISBN10: 0471880434, pp: 608.

Park, H.J., S.W. Jeong, J.K. yang, B.G. Kim and S.M. Lee, 2007. Removal of heavy metals using waste egg-shell. J. Environ. Sci., 19: 1436-1441. DOI: 10.1016/S1001-0742(07)60234-4

Rios, C.A., C.D. Williams and C.L. Roberts, 2008. Removal of heavy metals from Acid Mine Drainage (AMD) using coal fly ash, natural clinker and synthetic zeolites. J. Hazardous Materials, 156: 2335. PMID: 18221835

Robinson-Lora, M.A. and R.A. Brennan, 2009a. Efficient metal removal and neutralization of acid mine drainage by crab-shell chitin and continuousflow conditions. Bioresource Technol., 100: 50635071. DOI: 10.1016/j.biortech.2008.11.063
Robinson-Lora, M.A. and R.A. Brennan, 2009b. The use of crabshell chitin for biological denitrification: Batch and column tests. Bioresource Technolol., 100: 534-541. DOI: 10.1016/j.biortech.2008.06.052

Skousen, J.G., A. Sexstone and P.F. Ziemkiewicz, 2000. Acid Mine Drainage Control and Treatment. In: Reclamation of Drastically Disturbed Lands. Barnhisel R.I., R.G. Darmody and W.L. Daniels (Eds.)., American Society of Agronomy, Madison, pp: 131-168.

Sneddon, I.R., M. Orueetxebarria, M.E. Hodson, P.F. Scho-field and E. Valsami-Jones, 2008. Field trial using bone meal amendments to remediate mine waste derived soil contaminated with zinc, lead and cadmium. Applied Geochem., 23: 2414-2424. DOI: 10.1016/j.apgeochem.2008.02.028

Stella, H.Y.L., 2008. Acid Mine Drainage at Mamut Copper Mine, Ranau, Sabah. MSc Thesis, Universiti Malaysia Sabah.

Suzuki, S. and S. Iwao, 1982. Cadmium, copper and zinc levels in the rice and rice field soil of Houston, Texas. Biol. Trace Elem. Resources, 4: 21-28. PMID: 24271911

Valsami-Jones, E., K.V. Ragnarsdottir, A. Putnis, D. Bos-bach and A.J. Kemp et al., 1998. The dissolution of apatite in the presence of aqueous metal cations at pH 2-7. Chem. Geol., 151: 215-233. DOI: 10.1016/S0009-2541(98)00081-3 